著作権等の理由により画像を掲載することができません。

\title{
Fixing the sky
}

\section{オゾン層破壞と地球温暖化}

Nature Vol.460(792-795)/ 13 August 2009

オゾン層破壊の問題を解決すべく策定されたモントリオール議定書では、地球温暖化については考慮されていなかった。しかし、 2 つの環境問題は、複雑な形で密接に関係している。

モントリオール議定書へ

8 月下旬、南極大陸には忌まわしい現象 が現れる。長い極地の冬が終わり、空に 太陽が戻ってくると、成層圏にある塩素系 化合物や臭素系化合物がオゾン層の一部 を破壊しはじめるのだ。オゾン層には有害 な太陽紫外線から地球表面を保護する「日 よけ」の役目があるが、南極大陸上空で
は数か月にわたって大量のオゾンが破壊 され、ついには穴があいてしまう。それ がオゾンホールだ。

この現象は 1970 年代末から毎年、春 がくるたびに起きていた。しかし、科学 者がその生成パターンに気がつき、論文 を執筆するまでには数年を要した。そして 1985 年、英国南極調査所の研究チーム
がオゾンホールに関する論文を Nature に 発表したのを契機に、世界の関心がに わかに高まったのである。同じころ、人間 が大気中に排出する污染物質によってオゾ ン層が破壊されやすいことも明らかになっ てきた。オゾンホールへの懸念は各国を 動かし、1987 年には、オゾン層破壊物 質の製造を段階的に中止する道筋が定め
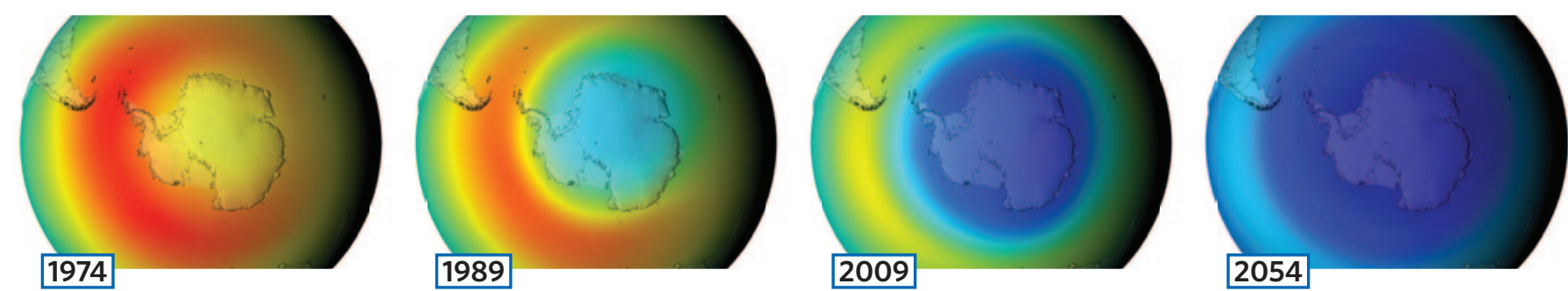

NASA のシミュレーションによると、塩素や臭素を含む污染物質が規制されていなかったら、南極大陸を覆うオゾン層の希薄化 (青色) はどんどん進行していたという。 
られた。この「オゾン層を破壊する物質 に関するモントリオール議定書」は、地球 規模の環境問題に対する最も野心的な取 り組みとして、今日も高く評価されている。

各国がモントリオール議定書に合意した ことで、地球の日よけを修復する作業は大 きく前進した。南極大陸上空に毎年出現 するオゾンホールは相変わらず大きいもの の、大気中の塩素の量は減少に転じている。 また、南極以外の地域でも、穴があくほど ではないが危険なほど薄くなっていたオソ ン層に、回復のきざしがみえはじめている。

\section{2つの地球環境問題}

明るいニュースがいくつか出てきた一方 で、いつになったら空が健康を取り戻せる のか、その大きな疑問への答えはまだ得 られていない。10 年前、研究者たちは、 オゾン層は 2050 年までに完全に回復す ると見積もっていた。しかし今日では、予 測は簡単ではないことがわかっている。予 想を困難にしている要因の 1 つが、温室 効果ガスの存在だ。モントリオール議定書 への署名から今日まで、温室効果ガスの 影響によって大気の状態は多くの点で変化 してきた。その中にはオゾン層の回復を 早める変化もあれば、回復を遅らせる変 化もある。

温室効果ガスの影響のうち、どれがオ ゾン層の回復に最も強く効いてくるかを検 証するには、長期シミュレーションが必要 である。その長期シミュレーションを実行 するには強力なコンピューターがいる。し かし、十分な性能を備えたコンピューター が出てきたのはつい最近のことだ。シミュ
レーションによれば、オゾン層の一部は、 従来考えられていた時期より数十年も早く 回復するが、南極のオゾンホールの回復 は、これまでの予想より数十年も遅くなる 可能性があることがわかった。

気候変動がオゾン層に影響を及ぼすよう に、オゾン層の変化もまた気候に対して影 響を及ぼす。南極大陸上空のオゾン層破 壊は、南極半島の温暖化を助長し、いく つかの棚水の崩壊を引き起こすなど、既 に気候に影響を及ぼしている。また、オ一 ストラリアでの干ばつと火災の増加の一因 となっている可能性も指摘されている。

米国海洋大気圏局（コロラド州ボール ダー）の大気化学者 Susan Solomonは、 「成層圏オゾンと地表の気候の間には、 さまざまな関連があります」という。「両 者の相互作用は非常に興味深いものです が、その全容はまだ解明されていません」。

\section{回避された最悪の未来}

オゾンホールの存在が広く知られるようにな る前から、科学者たちは、人間活動がオゾ ン層に及ぼす影響について心配しはじめて いた。1974 年には、カリフォルニア大学 アーバイン校（米国）の化学者 Sherwood Rowland と Mario Molina が、大気中に放 出されたクロロフルオロカーボン (CFC) 類 が成層圏に運ばれて分解されると、塩素原 子が生じてオゾン層を破壊する可能性がある と警告した ${ }^{2}$ 。彼らはのちにオゾン層の化学 の解明につながる先駆的な研究が認められ て、マックス・プランク化学研究所（ドイツ、 マインツ) の Paul Crutzen とともに 1995 年のノーベル化学賞を共同で受賞した。
地球規模のオゾン層の希薄化とオゾン ホールに対する懸念から生まれたモントリ オール議定書は、1987 年に採択され、 1990 年に発効した後も数度の改正を加 えられ、冷蔵庫、エアコン、発泡剂に使 用される CFC 類や、消火器に使用される ハロン（臭素を含むフルオロカーボン）な ど、オゾン層を破壊する能力が高い物質 の製造を禁止してきた。議定書の効果は すぐに現れ、成層圏のオゾン破壊物質の 実効濃度は1990 年代末にピークに達し た後、減少している ${ }^{3}$ 。

実は、モントリオール議定書による規制 は、地球温暖化対策としても有効である。 CFC 類をはじめとするフルオロカーボン類 （フロン）は、二酸化炭素よりもはるかに 強力な温室効果ガスだからだ。温室効果 ガスの削減という観点に立てば、実はフロ ンを規制するモントリオール議定書には京 都議定書の $5 \sim 6$ 倍の効果がある ${ }^{4}$ 。

「モントリオール議定書は、これまで策 定された環境国際法の中で最大の成功を おさめたもの」とSolomon はいう。「交 渉にかかわる人々は、温室効果ガスの規 制をもっとうまくやる必要があり、それは 可能です。この議定書が多くのことを教え てくれています」。

オゾン層を保護するための取り組みが 始まっていなかったら、未来の地球はどう なっていただろう？NASA ゴダード宇宙 飛行センター（メリーランド州グリーンベ ルト）の Paul Neuman とその同僚は、 化学反応、大気の循環、太陽放射をシミュ レーションするモデルを使って、オゾン層 を破壊する物質の製造が規制されず、年
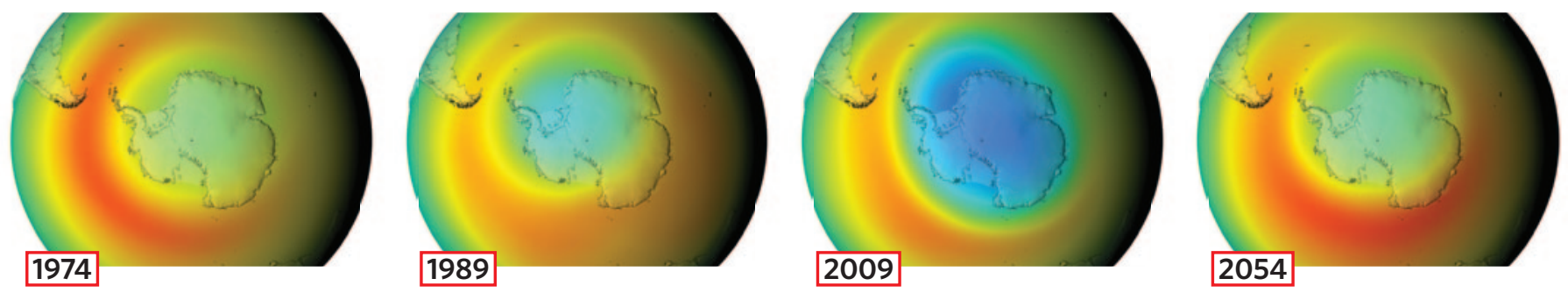

污染物質の規制により、今世紀の後半にはオゾン層の回復がはじまると予測されている。 
間 $3 \%$ ずつ増加しつづけた場合の未来 を予測してみた。その結果は、2065 年 までに、極地だけでなく地球全体で、才 ゾンの $2 / 3$ が破壊されるというものだっ た ${ }^{5}$ 。そして、フロンは今世紀の末までに 地球のオゾン層をほぼ完全に破壊してし まう。ニューヨーク、ブェノスアイレス、 東京をはじめとする中緯度地域（緯度が $30^{\circ} \sim 60^{\circ}$ の範囲にある温暖な地域）に 住む人々は、強烈な紫外線にさらされる ようになる。彼らは、日差しを 5 分間浴 びただけで危険な日焼けを起こす。これ は、今日の $1 / 3$ の時間である。DNAに 突然変異を引き起こす紫外線放射の強さ は約 6 倍になり、皮膚がんの患者数が激 増するだろう（p.14コラム「オゾン層と がん」参照)。
しかし、オゾン層保護条約のおかげで、 私たちが住む今の地球は太陽から降り注 ぐ恐ろしい紫外線から保護されている。 ミュンヘン近郊のオーバーファッフェン ホーフェンにあるドイツ航空宇宙センター の大気気候科学者 Martin Dameris は、「最 悪の未来は回避されました」という。「け れどもそれは、モントリオール議定書を骨 抜きにしようなどとは、ゆめゆめ考えては いけないという警告でもあります」。

\section{中緯度地域の現状と末来}

環境保護団体が特に心配しているのは、 農家が害虫駆除に使用する臭化メチルで ある。オゾン層保護条約の規定では、先 進国は2005 年まで、発展途上国はその 10 年後までに臭化メチルの使用が禁止さ

\section{オゾンの長い旅}

オゾン分子は熱帯地域上空の成層圏で生成し、両極地域に運ばれて、成層 圏下層に沈み込む。南極大陸の上空には気流が渦を作っていて（極渦）、 冬から春にかけて極地の成層圏を孤立させる。ここに封じ込められた冷た い空気が、春のオゾンホールの形成を促進する。

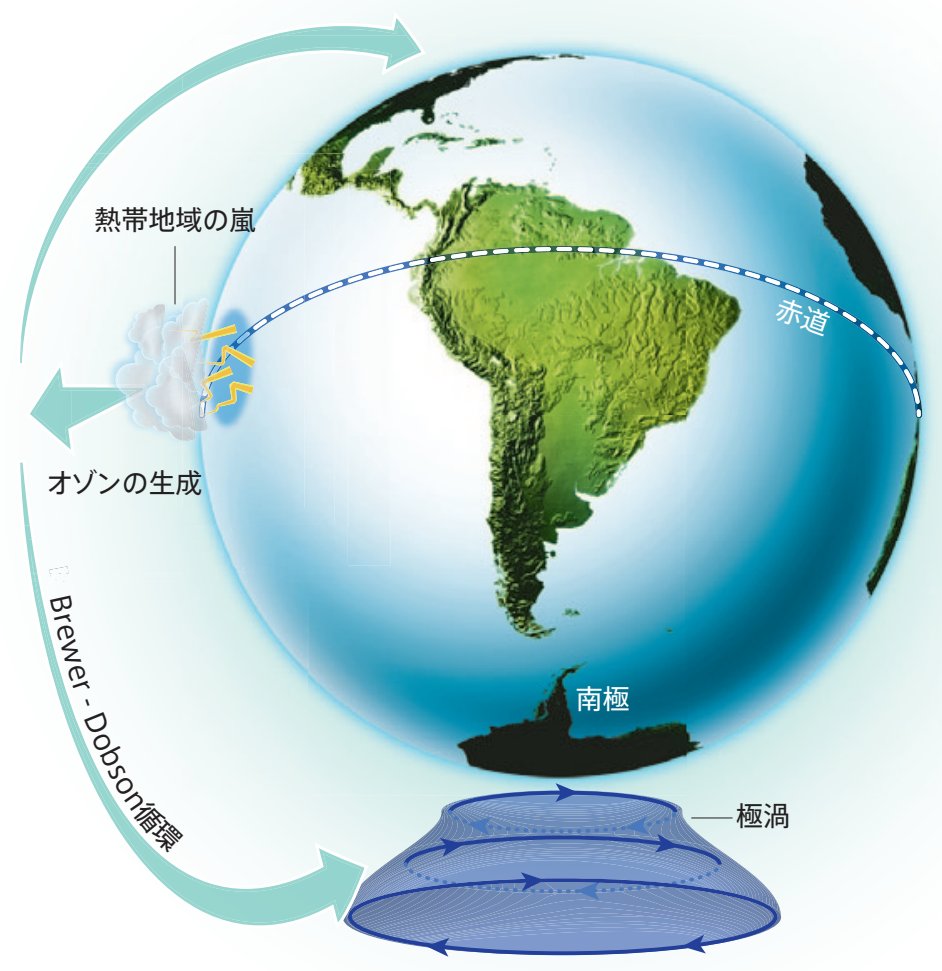

れることになっていた。しかし、農業団体 によるロビー活動の結果、臭化メチルの 禁止は回避され、今日も多くの先進国で 使用されている。

事態を複雑にしているもう１つの要因 は、旧型のエアコンや消火器に大量に 使われている塩素と臭素を含むフルオ口 カーボン類である。これらの大半も、や がては大気中に出ていく。塩素や臭素を 含むこれらの物質は、CFCなどのオゾン 層破壊物質が段階的に禁止されても、既 に製造されている装置や機器から放出さ れ続け、その後も数十年にわたって大気 中に滞留し、オゾンを分解し続けること になる。

現在、地球全体の成層圏のオゾン濃度 は 1964 年〜 80 年の平均值よりも約 4\% 低くなっている。しかし、その減少幅は、 南北半球によっても緯度によっても大きく 異なる。熱帯地域では、オゾン濃度はあ まり低下していない。これに対して中緯 度地域では、オゾン濃度が低下した極地 の大気塊と混ざりやすいため、1980 年 のオゾン濃度に比べて、北半球では合計 $3 \%$ 、南半球では $6 \%$ も低下している 3 。

中緯度地域におけるオゾン層破壊は、 毎年春に南極大陸で起こるオゾン層の大 規模な破壊に比べれば軽度であるが、こ の地域には人口が密集しているため影響 は大きい。地表に降り注ぐ紫外線量の増 加は、全世界の皮膚がんの発生件数を毎 年数十万件も増加させる可能性がある。 さらに、その影響が完全に現れるのは数 十年も先になるかもしれないのだる。

しかし、中緯度地域には希望もある。 この地域のオゾン濃度が上昇に転じる気 配をみせているからである。「中緯度地域 のオゾン濃度は、今後、上昇していくよう に思われます」と、ゴダード宇宙飛行セン ターの大気化学者 Richard Stolarsky はい う。彼によると、上昇傾向はまだ十分明 確にはなっていないため、その原因を特 定することはできないという。「けれども 私たちは、大気中の塩素濃度の低下がオ 
ゾン濃度の上昇に寄与していることに、か なりの確信をもっています」。

かつては中緯度地域のオゾン層が完全 に回復するのは 2050 年になると予測さ れていたが、現在のモデルを使ったシミュ レーションは、その時期が 20 年ほど早ま ることを示している。これは特に、南極の オゾンホールの影響をあまり受けない北 半球に当てはまる ${ }^{6}$ 。皮肉なことに、この オゾン層の回復の早まりは、地球温暖化 がもたらす恩恵とみることができる。温室 効果ガスが大気圏下層に熱を閉じ込める と、その上にある成層圏の温度を下げて、 オゾンを破壊する化学反応の速度を遅くす るのだ。さらに、気候と大気化学のシミュ レーションからは、オゾンを豊富に含む熱 帯地域の大気が中緯度地域に運ばれる循 環パターンが、地球温暖化によって加速さ れ、中緯度地域のオゾン濃度が上昇する と示唆される。

\section{極域の未来}

しかし、地球温暖化が両極付近に及ぼす 影響についての詳細は不明である。特に、 南極のオゾンホールがどうなっていくかは わからない。南極大陸上空の非常に乾燥 した成層圏の気温が $-78^{\circ} \mathrm{C}$ 以下になると、 極成層圏雲が形成され、この雲を構成す る水の粒子の表面で、3 個の酸素原子か らなるオゾン分子の酸素原子を 1 個はぎと る化学反応が起こる。したがって、南極大 陸上空の成層圏の温度が下がれば、オソ ン破壊は促進される可能性がある。

水の粒子の役割は大きい。極地以外の 成層圏では、塩素原子は平均すると数百 個のオゾン分子を破壞したあと、亜酸化 窒素などの気体分子と反応して活性を失 う。しかし極地の成層圏では、水粒子の 表面が触媒として作用し、数万個のオゾン 分子を破壊することができる。その反応は 高速である。南極のオゾンホールの中心 部では、地表から $14 \sim 21 \mathrm{~km}$ の範囲に あるオゾンの $3 \%$ が 1 日で破壊されてしま うこともある3 ${ }^{3}$ 。10月の初旬までに、極
成層圏雲はこの高度にあるオゾン分子を ほとんどすべて破壊してしまう。

1992 年、温室効果ガスによる温暖化 がオゾン破壊を大幅に加速し、北極上空 にもオゾンホールを形成させるという予測 が発表された ${ }^{7}$ 。この論文の著者であり、 地球物理流体力学研究所 (米国、二ュー ジャージー州プリンストン）のモデル製作 者であるJohn Austin によると、その研 究では重要な効果を考慮していなかった。 地球大気には Brewer - Dobson 循環とい う流れがある。これは、熱帯地域の空気 を成層圏まで上昇させ、高緯度地域に運 び、そこで大気圏下層に下降させる流れ である（空気はこのとき圧縮され、温度 が上昇する)。気候変動でこの周期が加速 されるなら、極地上空で下降する気流も速 くなる。その結果、下降する空気はより強 く圧縮されて、そこの気温を上昇させる。 特に北極では、成層圏の温度上昇はオソ ンの破壊を阻止するとAustin はいう。

気候変動は、極地の成層圈の温度を 上昇させる方向にも低下させる方向にも 作用するため、どちらの効果が卓越する のか、研究者たちはまだ判断できずにい る。ジョンズホプキンス大学（米国、メ リーランド州ボルティモア）の大気科学者 Darryn Waugh によると、その結果はモ デルによってまちまちであり、かなりの不 確実性が残っているという。

この分野の進展を妨げている要因の 1 つは、研究に要する時間の長さである。 大気化学と気候の両方を再現できる複雑 なモデルを、長期にわたってシミュレー ションできるコンピューターはまだ少ない。 Austin によると、プリンストン高等研究所 で 100 年分のシミュレーションを行うため には、100 台のプロセッサからなるシス テムを使って 3 か月間連続で計算しなけ ればならない。実験が中断しないよう「毎 日見守らなければなりません」と彼はいう。 「さもないと、3 か月の予定が、すぐに 4 か月、 5 か月に延びてしまうからです」。 現時点では、南極大陸上空のオゾンホー

\section{効果的だった条約}

モントリオール議定書が採択され、数度に わたって改正されていなかったら、オゾン 層を破壊する化合物の量は増え続け、皮膚 がんの発生率は急増していただろう。

\section{オゾン層を破壊する化合物の量}

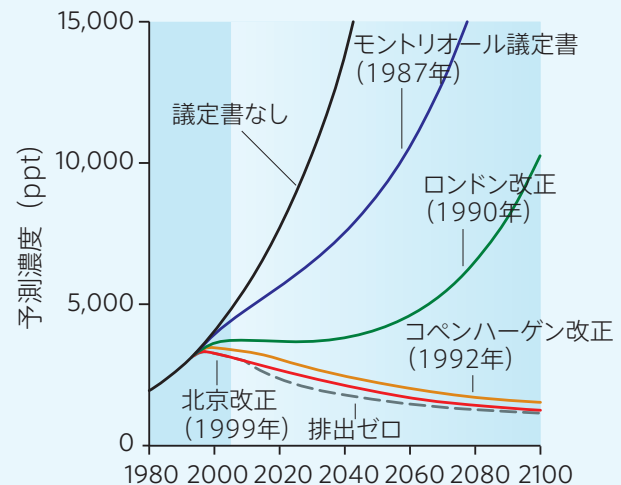

皮膚がん患者の増加数

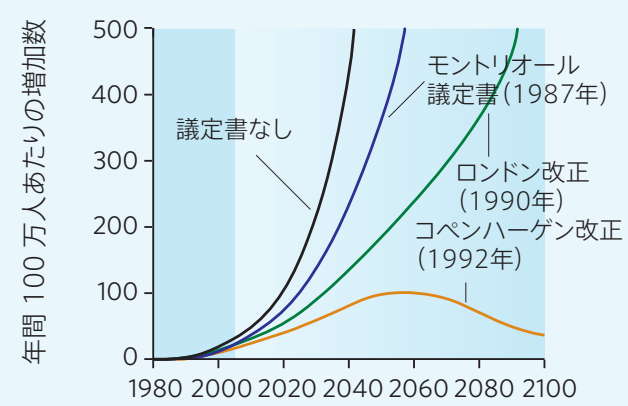

ルが回復するきざしはまったくみられな い。2002 年と 2004 年には比較的軽度 だったが、2006 年にはオゾン濃度は最低 記録を更新し、その後も低いままである。 ほとんどの科学者は、今後 20 年以内に 回復が始まることはないと考えている。5 年前の予想に比べると、回復時期は 10 年あまり遅くなったことになる。これは、 大気中の化学物質の移動をシミュレーショ ンしたところ、南極大陸上空の成層圏オゾ ン層破壊物質が、今後 10 年から 20 年 間は飽和したままであるという結果になっ たからである。多くのモデルによると、極 地でのオゾン層破壊物質の濃度が 1980 
年代の值よりも低くなり、オゾンホールが ほぼ完全に消えて元に戻るのは、2060 年から 2065 年頃になるという。

最新のモデル実験の結果から、新たな 複雑化要因の存在が明らかになった。そ れが既に述べた臭素系化合物の影響であ る。成層圏の臭素濃度がモデルの示唆す る濃度より高いのは、予測よりも多くの臭 素が成層圏に流入しているからだと考えら れる。プリンストン高等研究所の研究によ ると、この傾向が続くなら、2065 年以降 も数十年にわたって、現在のオゾンホー ルの 1/10 程度の小さなオゾンホールが 形成されつづけることになる。Austin は、 この結果は予備的なものにすぎないと念 を押したうえで、「今世紀の終わりになっ ても、オゾンホールは完全にはなくならな いでしょう」という。

\section{オゾン層破壊が気候変動を起こす}

しかし、人間にとっても大部分の動植物に とっても、オゾンホールから余分に降り注 いでくる紫外線は、あまり大きな問題には ならないかもしれない。オゾン層破壊が ピークに達するのは早春であり、太陽の 高度はまだ低いため、地表に届く紫外線 はたいした量にはならないからだ。
「オゾンホールが 1 個なければならない のなら、南極大陸にあるのがいちばん都 合がよいのです」とSolomon はいう。「オ ゾンホールが熱帯地域にあったら、生物 に甚大な悪影響を及ぼしていたでしょう」。

しかし、オゾンホールはわずかに多くの 紫外線放射を入れてしまうだけでなく、狭 い範囲の気候に間接的な影響を及ぼし、 南半球の広い範囲で実感されるような大 気の変化を引き起こす。そもそも太陽紫外 線を吸収するオゾンは、成層圏にとっては 巨大な熱源である。極地の成層圏の広い 範囲でオゾン層が破壊されたことで、この 領域は $6^{\circ} \mathrm{C}$ 近く低下している。Solomon は、この冷却効果が極冠の周囲を吹く西 風の渦を強化し、南極大陸の封じ込めを 助長していることを明らかにした8 ${ }^{8}$

この発見から、南極大陸の気候が示す いくつかの不思議な特徵を説明することが できる。強い極渦は、低温の空気を内陸 の高原に閉じ込めることで、地球上で最も 寒い地域を温室効果ガスによる温度上昇 から保護している。南極大陸の大部分の 気温は、この 30 年間に低下してきた。こ れは、地球温暖化を否定する人々がしば しば証拠として挙げる事実である。しかし、 Solomon の研究は、南極大陸の内陸部
で温度が上昇していないことはオゾン層の 破壊によって理解できることを示している。 南極大陸上空に封じ込められた冷たい 空気が、大陸の縁を越えて外に流れ出すこ とは少ない。このことは、比較的穏やかな 海洋性気団にさらされている南極半島が、 地球上で最も急速に温暖化した事実を理 解する助けになる。過去数年間に、南極 半島では 2 つの大きな棚水が離れ、南極 海に巨大な水山を送り出した。そのほか 6 つの棚水が崩壊の徴候を示している。

今後、オゾンホールが縮小するにつれ、 南極大陸上空に封じ込められていた空気 は解放されていくだろう。「極渦はゆるく なり、内陸部の冷たい空気は、もっと頻 繁に南極半島に到達できるようになりま す」とSolomon。「これはよい傾向です」。

南極大陸の周囲、例えばロス海では、 海水に覆われている海面の割合が上昇し ている。Solomonは早い時期から、この 一見不可解な傾向の背景にも、南極大陸 の周囲で大気の循環が強くなったことが関 係していると指摘してきた。実際、最近の モデル実験では、海水の拡大と南極大陸 全体の気候変化は、オゾンホールが大気 の循環パターンを変えたことにより説明で きることが確認されている ${ }^{9}$ 。

\section{オゾン層とがん}

過去 30 年間に地球のオゾン 層が希薄化したことに伴い、 皮膚がんの発生率が急増する ことが予想された。実際、増 加は起きたようにみえる。米国 では 2009 年、 6 万 9000 件 の黒色腫が診断されると予想 されているが、これは 1975 年の 2 倍にあたる数字であ る。黒色腫の発生率と死亡率 が世界一高いオーストラリアと ニュージーランドの一部の地域 では、この数字は1994 年か
ら50\%も増加している。

しかし、皮膚がん患者の増 加がオゾン層破壊に起因して いると断定するのは難しい。 なぜなら、皮膚がんの発生率 は、オゾン層破壊以外の要因 (例えば、生活様式、日焼け 止めの使用、腫瘍の診断頻度 など）にも依存し、これらは いずれも時代とともに変わって くるからである。また、紫外線 に曝露してから皮膚がんを発 症するまでには数十年かかる
ため、これまでのオゾン層の 希薄化に起因する皮膚がんの 増加のピークはまだ到来して いないと考えられる。

世界気象機関と国連環境計 画は、紫外線放射の予測増加 量に基づき、オゾン層以外の 要因が不変であると仮定して、 皮膚がんの患者数は今世紀の 中頃にピークに達し、1980 年の水準に比べて年間 100 万 人あたり 100 人あまり増加す ると予測した。全世界では 70
万人増えることになる。その 後、患者数は 1980 年の水準 に戻っていくという。

モントリオール議定書が採 択されず、その後の改定も行 われていなかったら、皮膚が んの患者数は 2050 年には 4 倍になり、その後も急激に増 加していたと考えられている 3 (13 ページの図参照)。

Q.S. 
モナッシュ大学気象力学海洋学センター (オーストラリア、クレイトン) の James Risbey は、オゾン層の破壊は南極大陸 以外にも影響を及ぼしており、オーストラ リア南部での雨量の減少と干ばつの増加 を引き起こしたと指摘する。彼によると、 これまた南極大陸上空のオゾン層が破壊 されたことで気温と気圧が低下し、極渦 の風速が上がったことが原因であるという (12ページの図参照)。その結果、雨を 降らせる西風が南下し、オーストラリアか ら遠ざかってしまった。Risbey は、南極 大陸上空のオゾン層破壊はオーストラリア の乾季の雨量を $20 \%$ 減少させたと推測し ている。

\section{気候変動もまたオゾン層に影響する}

「オゾンの化学と大気の力学は相互に影響 を及ぼし合います。そのため、どちらがど のような影響を及ぼしているかを分けて論
じることは困難なのです」と Dameris は いう。「多くはまだ推測の域を出ていませ ん。今後、思いがけない発見もあるかも しれません」。

気候と大気化学をシミュレーションする 彼のモデル実験は、熱帯地域の海面温度 の上昇が Brewer - Dobson 循環を強化 することを示唆している ${ }^{10}$ 。これにより、 熱帯地域上空のオゾンが減少し、それ以 外の地域のオゾンが増加して、中緯度地 域のオゾン濃度が異常に高くなる可能性 がある。増えたオゾンは人間を保護する のに役立つかもしれないが、成層圏の化 学反応を変えたり、植物の成長を遅らせ たりして悪影響を及ぼす可能性もあると Dameris は言う。

これまで、人間活動が空のオゾン濃度 に及ぼす影響としては、塩素や臭素によ る反応が大きかった。長期的には、こう した污染物質は空から除去されていくの
で、やがては温室効果ガスの影響が主役 になっていく。それゆえ、「気候変動がオ ゾン層に及ぼす影響について考えている 人はあまりいませんが、そろそろ目を向け る必要があります」。(三枝小夜子 訳)

Quirin Schiermeier はドイツに拠点を置くNature の 通信員。Richard Monastersky が追加報告を行って いる。

1. Farman, J. C., Gardiner, B. G. \& Shanklin, J. D. Nature 315, 207.210 (1985)

2 Molina, M. J. \& Rowland, F. S. Nature 249, 810.812 (1974).

3. United Nations Environment Programme Scientific Assessment of Ozone Depletion: 2006 (UNEP, 2007) available at www.unep.ch/ozone/Assessment_Panels/ SAP/Scientific_Assessment_2006/index.shtml.

4. Velders, G. J. M. Andersen, S. O., Daniel, J. S., Fahey, D. W. \& McFarland, M. Proc. Natl Acad. Sci. USA 104, 4814.4819 (2007).

5. Newman, P. et al. Atmos. Chem. Phys. 9, 2113.2128 (2009).

6. Waugh, D. W. et. al. Geophys. Res. Lett. 36, L03805 (2009).

7. Austin, J., Butchart, N. \& Shine, K. P. Nature 360, 221.225 (1992).

8. Thompson, D. W. J. \& Solomon, S. Science 296, 895.899 (2002).

9. Turner, J. et al. Geophys. Res. Lett. 36, L08502 (2009).

10. Deckert, R. \& Dameris, M. Geophys. Res. Lett. 35, L10813 (2008). 